\title{
Redactioneel: Blinde vlekken
}

Stadslucht maakt vrij. Mensen in de stad zijn immers kosmopolitisch, tolerant en waarderen diversiteit. De bruisende en vrije stad tegenover het bekrompen platteland of - recenter - het saaie suburbia. Toch valt op dit beeld wel wat af te dingen. Veel stadsbewoners verlaten hun veilige biotoop nauwelijks, slechts voor een familiebezoek, of een stedentripje naar Berlijn of Londen. Al wat zich buiten dit stedelijke netwerk bevindt, valt buiten het het blikveld.

Charleroi is een uitstekend voorbeeld van zo'n blinde vlek. Eens het bloeiende centrum van de Waalse staalindustrie, nu vooral bekend om haar werkloosheid en verval. Een tijdje terug besloot ik het gebied te bezoeken. Een keer niet naar Gent, Brugge of Antwerpen, maar een andere kant van België. Het is een ontnuchterende ervaring. Niet eens zozeer vanwege het roestende industrieel erfgoed - hier valt nog wel iets artistieks in te zien. Het is vooral de levenswijze van de bewoners die je uit je hoogstedelijke cocon wakker schudt. Wanneer we 's ochtends om een uur of tien een kopje koffie drinken, zit het cafe afgeladen met buurtbewoners die het bier rijkelijk laten vloeien. Geen Latte Macchiato om wakker te worden, maar een pint met een schuimkraag.

ledereen heeft zo zijn gewoontes. Zelf ga ik regelmatig naar het Oosterpark in Amsterdam. Bij gebrek aan een tuin fungeert het als mijn buitenruimte. Er is meer dan genoeg te doen: hardlopen, picknicken, festivals bezoeken. Het park is inmiddels zo populair dat het de vraag bijna niet meer aankan. Buurtbewoners, festivalgangers, alcoholisten, natuurliefhebbers; allemaal claimen ze wat dichter J.C. Bloem ooit 'een stukje bos ter grootte van een krant' noemde. De volgende AGORA over Groene Ruimte gaat de diepte in over dit boeiende onderwerp. Een thema dat verrassend genoeg dwarsverbanden kent met voorliggend nummer over Seksualiteit.

Een voorstel om het Oosterpark 's nachts af te sluiten om de overlast van alcoholisten in het park tegen te gaan stuitte namelijk op protest van een andere groep: mannelijke cruisers die de bossages 's nachts

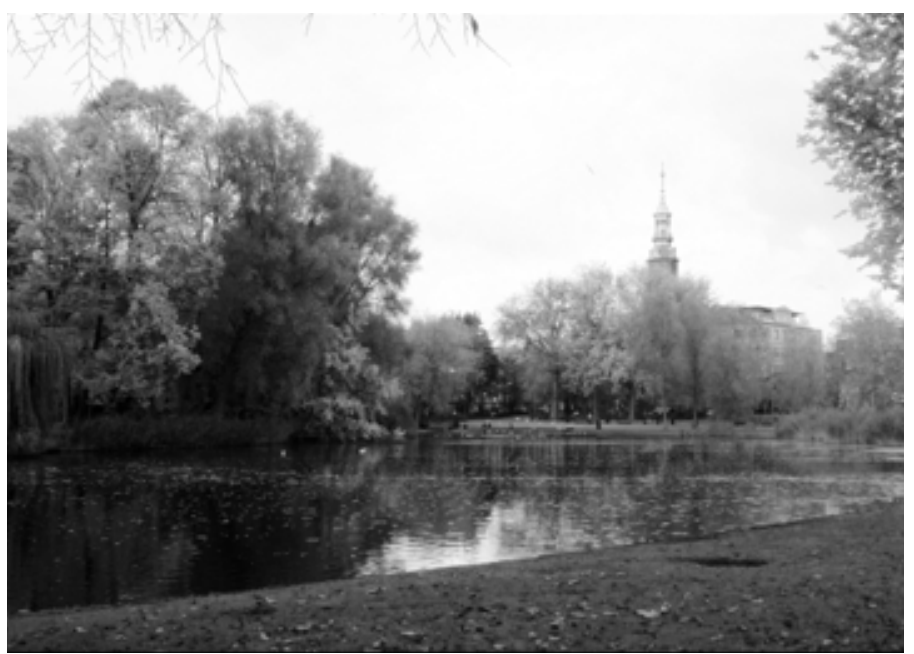

Het Oosterpark in Amsterdam. Foto Charles Roffey (CC BY-NC-SA)

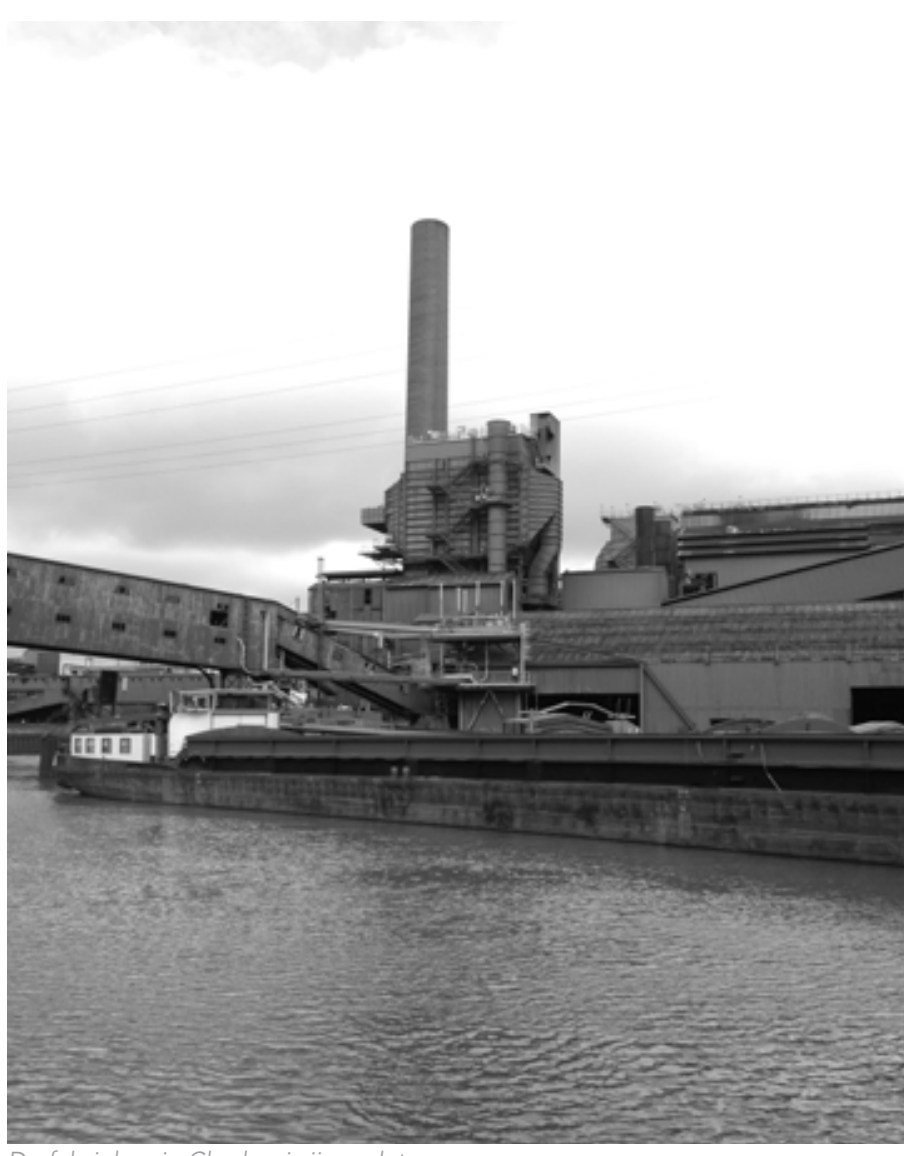

De fabrieken in Charleroi zijn verlaten.

gebruiken als afspreekplaats voor seksuele handelingen. De bezwaren werden gehonoreerd. Het Oosterpark blijft ook 's nachts open, mits de gebruikte voorbehoedsmiddelen netjes worden opgeruimd. Vrijwilligers die het park schoonmaken hadden namelijk geklaagd over de vele condooms in de vijver.

Voordat ik me in het park ging verdiepen was deze situatie me onbekend. Blinde vlekken gelden net zo goed voor de eigen achtertuin als de roestende staalovens van Charleroi. Het wegnemen van blinde vlekken gaat niet zonder slag of stoot, want mensen zijn in veel gevallen bewust blind voor ongemakkelijke zaken. Wetenschappelijk onderzoek kan bijdragen aan het verhelpen van blindheid. In deze AGORA een aantal fascinerende voorbeelden. Neem de Klassieker van Louis van den Hengel. Hij laat zien hoe het werk van Michel Foucault ons helpt te reflecteren op het idee van seksuele vrijheid. "Hoe meer we opbiechten over seks, hoe meer macht we toekennen aan de instituties die het seksuele leven beheersen." Vrijheid is zowel in relatie tot stadslucht als seksualiteit een ingewikkeld concept. Geen twijfel is er over de vrijheid van de samenstellers van dit themanummer. Zij nemen met verrassende en soms expliciete invalshoeken een aantal van onze blinde vlekken omtrent seksualiteit weg.

Peter Pelzer, Hoofdredacteur AGORA 